\title{
A Decision-Making Algorithm for Energo-Economic Sustainability and Efficiency in Buildings: A Case Study in Turkey
}

\author{
Derya Kışla Tekin ${ }^{1}$, Levent Çolak, Birol Kılkış \\ ${ }^{1}$ Department of Energy Engineering, Başkent Univerisity- Bağlica Campus, Ankara, Turkey
}

\begin{abstract}
Today, sustainability and energy efficiency are of prime importance in satisfaction of thermal and electrical loads of buildings. In this study, innovative hybrid solutions alternative to conventional HVAC systems are investigated. Objective of study is to minimize the payback period and $\mathrm{CO}_{2}$ emissions are main objectives. For conventional HVAC systems two sources of energy, namely natural gas and electricity were considered as the base line. Energy sources for the innovative methods were considered to be solar energy, ground heat and waste heat. Conventional system was considered to be a backup system when innovative energy resources are insufficient. Hourly heating, cooling and electrical power loads of Eser Green Building, which already has LEED Platinum certificate were used for the case study, which aims to further improve the energy and exergy efficiency. In the new algorithm being developed, all power conversion systems were defined in a simple input- output transfer function format. A decision-making algorithm and an Excel ${ }^{\mathrm{TM}}$-based simulation program were developed and tried with Eser Green Building input data for different renewable energy source and system combination conventional systems, energy sources, and equipment in term of investment, operation and total cost, payback period, and carbon dioxide emission values. Payback period of Eser green building is 11,8 years and for two hybrid systems are 13,2 years and 9,2 years, respectively. Carbon dioxide emissions by hybrid systems under the same load conditions were found to be $488 \mathrm{kgCO}_{2} / \mathrm{h}$ and $592 \mathrm{kgCO}_{2} / \mathrm{h}$ for approaches, respectively.
\end{abstract}

\section{Introduction}

Nowadays, the heating and domestic hot water loads in buildings are generally satisfied by natural gas. Grid electricity is used for cooling either by heat pumps or chillers. This method has strong implications on global warming and ozone depletion, while the grid electricity is still provided by fossil fuels. Therefore, innovative methods of sustainability and energy efficiency need be developed. The use of energy resources such as renewable energy, ground heat, waste heat and integration these resources with the buildings has become a necessity for sustainability. Iodice et al. [1] discussed two different power plants in their study. In this study natural gas and vegetable oil were used as primary energy resources, respectively in those scenarios. Payback periods were 7.3 years, and 4.6 years for natural gas and vegetable oil, respectively. Yazman [2] has developed a solution to meet building loads with the tri-generation unit against the conventional method. As a result of that $26.5 \%$ energy saving was achieved and the payback period was 3.22 years. Memon [3] further studied the economy of tri-generation systems. Depending on the heating, power, and cooling capacities, the investment costs varied between $\$ 13 / \mathrm{kWh}-1500$ $\$ / \mathrm{kWh}$ and the payback period varied till 11 years. Zhao et al. [4] studied on the tri-generation system and its operation in two different modes of operation, namely winter and summer. At full load, the maximum energy efficiency calculated in winter $94 \%$ and summer is $84 \%$ in. The maximum First-Law efficiency (simple sum of power and heat partial efficiencies) calculated in winter was $38 \%$ and in summer was $36 \%$. The purpose of this study is to examine the benefits of using innovative technologies or retro filling existing buildings with them on the basis of economy and environment. In addition, economic decision-making support algorithm is developed and the shortest payback period and the carbon dioxide emission is minimized. In this context, the main building loads are considered as cooling, heating, electricity and hot water.

\section{System Description}

The innovative method, which compares to the conventional method used in meeting building loads, has been analysed technically, economically, and environmentally. A mathematical model was developed. Eser Green Building's building loads were used. The most important output is the decision making algorithm. Additionally the function of the objective can be shaped depending on the needs of the user.

\subsection{Technical Parameters}

In the innovative system, the energy sources are ground heat, renewable energy and waste heat. Ground temperature rises as the depth increases, and this value is approximately $0.03{ }^{\circ} \mathrm{C}$ per meter [5]. Heating and cooling can be achieved by controlling the panel temperature of a radiant panel system. Depending on the region where the building is located, it is possible to diversify the renewable energy sources, and one of the many advantages of solar energy is the renewable energy source. For the conventional system that is considered to be a back-up relies on two main sources of energy, namely natural gas and mains electricity. The capacity of the innovative power conversions to be used to meet the building loads is determined according to the base building loads and the peak loads go to the conventional back-up system.

\footnotetext{
* Corresponding author: drykisla@hotmail.com
} 
The energy source of the power conversion systems, the purpose of the use of power conversion systems, input and output are shared in Table 1. When designing an innovative hybrid system, the energy efficiency of the selected power conversion systems has been taken into consideration and at least 4 months of the year in this regard has been noted to be used.

\subsection{Environmental Parameters}

There are two kinds of carbon dioxide emission sources such as electricity production plants and on site combustion of natural gas. In this study, the emission of carbon dioxide during the production and logistics of power conversion systems has not been included in the calculation of environmental parameters. The contribution of energy converting systems used as solar energy to carbon dioxide emission is not included in the calculation of environmental parameters in this study. In the equations numbered 1 and 2 , carbon dioxide emission values from natural gas $\left(G_{\mathrm{n}, \mathrm{t}}\right)$ and electricity $(\mathrm{Ge}, \mathrm{t})$ consumption were shared. As a result of the natural gas and electricity consumption of the power converting systems, the total carbon dioxide emission value $(E)$ and the carbon market-determined unit value $\left(P_{c}\right)$ multiply by the total carbon cost $\left(T C_{\mathrm{c}}\right)$. The total carbon cost will be the profit entry for the payback period, which is the purpose of the study.

$$
\begin{aligned}
& G_{\mathrm{n}, \mathrm{t}}=\left(\sum G_{\mathrm{n}, \mathrm{ii}}+\sum G_{\mathrm{n}, \mathrm{ci}}\right) x c_{1} \\
& G_{\mathrm{e}, \mathrm{t}}=\left(\sum G_{\mathrm{e}, \mathrm{ii}}+\sum G_{\mathrm{e}, \mathrm{ii}}\right) x c_{2} \\
& E=G_{\mathrm{n}, \mathrm{t}}+G_{\mathrm{e}, \mathrm{t}} \\
& T C_{\mathrm{c}}=\mathrm{E} x P_{c}
\end{aligned}
$$

\subsection{Economical Parameters}

In this part of the study, economic evaluation of a project and determination of payback period as main output are discussed. The main parameters of the economic analysis are investment cost, operating cost, total cost and payback period. The total cost is defined in equation number 5 .

$$
T C=\sum I C_{\mathrm{i}}+\sum O C_{\mathrm{i}}
$$

Although the cost of the investment and the operation cost of the conventional method and the innovative method used to meet the building loads are similar, they are separated at some points. In the study, the investment cost is included in the calculation by taking the unit $\mathrm{kW}$ prices into account according to the capacity and type of power conversion system. The investment costs of power converting systems are also reflected in the installation costs of power converting systems. The total investment cost is the sum of the investment costs of the power converting systems used in the conventional system and the innovative system defined in equation 6 .

$$
I C_{\mathrm{t}}=\Sigma I C_{\mathrm{i}}
$$

Maintenance and other expenses have been taken as a proportion of the total cost when calculated operation cost. The maintenance and other costs for the innovative system are reflected in the economic analysis account for $5 \%$ for the summer season and 5\% for the winter season. The depreciation of power conversion systems is not included in the operating cost calculation. In conventional systems, the operating costs is calculated by taking into account the natural gas and electricity consumption. The operating cost of the innovative method differs depending on the energy source of the power converting systems in the hybrid system. These energy sources are natural gas, electricity, waste heat, ground heat and renewable energy. Since there is no fuel or electricity consumption affecting the operating cost of renewable energy, ground temperature and waste heat, the calculations are neglected. In hybrid systems consisting of different power converters, multiple power converters meet the same load and meet the load, in which case the power ratio of the power converters is taken into account. In order to meet the same load, the sum of the coverage ratios of the power converter systems working together is equal to a maximum of 1 . The following equations correspondence ratio is formulated.

$$
\begin{aligned}
& C R=C_{\mathrm{i}} / \mathrm{C}_{\mathrm{j}} \\
& \sum C R_{\mathrm{i}}=1
\end{aligned}
$$

The payback period, which is the objective function of the study, is formulated as follows;

$$
P P=\left(I C_{\mathrm{t}, \mathrm{c}}\right) /\left(O C_{\mathrm{t}, \mathrm{k}}-\left(O C_{\mathrm{t}, \mathrm{i}}-T C_{\mathrm{c}}\right)\right)(9)
$$

In the study, the weakest link in the hybrid system created by the combination of power transformer systems is considered in determining the project life. The life span of $\mathrm{PV}$, which is the shortest power-converting system in the hybrid system, is determined as the life of the project and this period is 15 years. 


\begin{tabular}{|c|c|c|c|c|c|c|c|c|}
\hline $\begin{array}{l}\text { Energy } \\
\text { Source }\end{array}$ & $\begin{array}{l}\text { Power Con- } \\
\text { version Sys- } \\
\text { tem }\end{array}$ & Purpose & Input & Parameter & Unit & Transfer Function & Output & Unit \\
\hline \multirow{17}{*}{$\begin{array}{l}\text { Solar } \\
\text { Energy }\end{array}$} & \multirow{6}{*}{$\begin{array}{l}\text { Photovoltaic } \\
\text { Panel }\end{array}$} & \multirow{6}{*}{ Electricity } & \multirow{6}{*}{$\begin{array}{l}\text { Solar Ra- } \\
\text { diation }\end{array}$} & Total Radiation & $\begin{array}{l}\mathrm{kWh} / \\
\mathrm{m}^{2} / \text { year }\end{array}$ & \multirow{6}{*}{$\mathrm{y}_{\mathrm{e}}=\mathrm{W} / \mathrm{I}$} & \multirow{6}{*}{ Electricity } & \multirow{6}{*}{$\mathrm{kW}$} \\
\hline & & & & $\begin{array}{l}\text { Sunshine Dura- } \\
\text { tion }\end{array}$ & ${ }^{\circ} \mathrm{C}$ & & & \\
\hline & & & & Panel Efficiency & - & & & \\
\hline & & & & Surface Area & $\mathrm{m}^{2}$ & & & \\
\hline & & & & Panel Type & - & & & \\
\hline & & & & $\begin{array}{l}\text { Initial Investment } \\
\text { Cost }\end{array}$ & $\$$ & & & \\
\hline & \multirow{7}{*}{$\begin{array}{l}\text { Photovoltaic } \\
\text { Thermal Hy- } \\
\text { brid Panel }\end{array}$} & \multirow{7}{*}{$\begin{array}{l}\text { Electricity } \\
\text { Heat }\end{array}$} & \multirow{7}{*}{$\begin{array}{l}\text { Solar Ra- } \\
\text { diation }\end{array}$} & Total Radiation & $\begin{array}{l}\mathrm{kWh} / \\
\mathrm{m}^{2} / \text { year }\end{array}$ & \multirow{3}{*}{$\mathrm{y}_{\mathrm{h}}=\mathrm{Q}_{\mathrm{h}} / \mathrm{IxA}_{\mathrm{PV} / \mathrm{T}}$} & \multirow{7}{*}{ Electricity } & \multirow{7}{*}{$\mathrm{kW}$} \\
\hline & & & & $\begin{array}{l}\text { Panel Heat Effi- } \\
\text { ciency }\end{array}$ & - & & & \\
\hline & & & & $\begin{array}{l}\text { Panel Electricity } \\
\text { Efficiency }\end{array}$ & - & & & \\
\hline & & & & Surface Area & $\mathrm{m}^{2}$ & \multirow{4}{*}{$\mathrm{ye}=\mathrm{W} / \mathrm{IxA}_{\mathrm{PV} / \mathrm{T}}$} & & \\
\hline & & & & $\begin{array}{l}\text { Sunshine Dura- } \\
\text { tion }\end{array}$ & $\mathrm{h}$ & & & \\
\hline & & & & Panel Type & - & & & \\
\hline & & & & $\begin{array}{l}\text { Initial Investment } \\
\text { Cost }\end{array}$ & $\$$ & & & \\
\hline & \multirow{4}{*}{$\begin{array}{l}\text { Flat Plate Col- } \\
\text { lector }\end{array}$} & \multirow{4}{*}{$\begin{array}{l}\text { Hot Wa- } \\
\text { ter }\end{array}$} & \multirow{4}{*}{$\begin{array}{l}\text { Solar Ra- } \\
\text { diation }\end{array}$} & Total Radiation & $\begin{array}{l}\mathrm{kWh} / \\
\mathrm{m}^{2} / \text { year }\end{array}$ & \multirow{4}{*}{$\mathrm{y}_{\mathrm{DT}}=\mathrm{Q}_{\mathrm{h}} / \mathrm{I}$} & \multirow{4}{*}{ Heat } & \multirow{4}{*}{$\mathrm{kW}$} \\
\hline & & & & Surface Area & $\mathrm{m}^{2}$ & & & \\
\hline & & & & $\begin{array}{l}\text { Collector Effi- } \\
\text { ciency }\end{array}$ & - & & & \\
\hline & & & & $\begin{array}{l}\text { Initial Investment } \\
\text { Cost }\end{array}$ & $\$$ & & & \\
\hline \multirow{14}{*}{$\begin{array}{l}\text { Waste } \\
\text { Heat }\end{array}$} & \multirow{5}{*}{$\begin{array}{l}\text { Absorption } \\
\text { Refrigeration } \\
\text { System }\end{array}$} & \multirow{5}{*}{ Cooling } & \multirow{5}{*}{$\begin{array}{l}\text { Heat } \\
\text { Electricity }\end{array}$} & Cooling Capacity & $\mathrm{kW}$ & \multirow{5}{*}{$\mathrm{COP}=\mathrm{Q}_{\mathrm{c}} / \mathrm{Q}_{\mathrm{h}}$} & \multirow{5}{*}{ Cooling } & \multirow{5}{*}{$\mathrm{kW}$} \\
\hline & & & & $\begin{array}{l}\text { Number of Influ- } \\
\text { ence }\end{array}$ & - & & & \\
\hline & & & & $\begin{array}{l}\text { Output Tempera- } \\
\text { ture of Fluid }\end{array}$ & ${ }^{\circ} \mathrm{C}$ & & & \\
\hline & & & & $\begin{array}{l}\text { Coefficient of } \\
\text { Performance } \\
\end{array}$ & - & & & \\
\hline & & & & $\begin{array}{l}\text { Initial Investment } \\
\text { Cost }\end{array}$ & $\$$ & & & \\
\hline & \multirow{4}{*}{$\begin{array}{l}\text { Desicant Re- } \\
\text { frigeration } \\
\text { System }\end{array}$} & \multirow{4}{*}{ Cooling } & & Cooling Capacity & $\mathrm{kW}$ & & & \\
\hline & & & & $\begin{array}{l}\text { Coefficient of } \\
\text { Performance }\end{array}$ & - & $\mathrm{COP}=\mathrm{Q}_{\mathrm{c}} / \mathrm{Q}_{\mathrm{h}}$ & & \\
\hline & & & Heat & $\begin{array}{l}\text { Input Tempera- } \\
\text { ture }\end{array}$ & ${ }^{\circ} \mathrm{C}$ & & Cooling & $\mathrm{kW}$ \\
\hline & & & & $\begin{array}{l}\text { Initial Investment } \\
\text { Cost }\end{array}$ & $\$$ & & & \\
\hline & & & & Cooling Capacity & $\mathrm{kW}$ & & & \\
\hline & & & & $\begin{array}{l}\text { Number of Influ- } \\
\text { ence }\end{array}$ & - & & & \\
\hline & $\begin{array}{l}\text { Adsorption } \\
\text { Refrigeration }\end{array}$ & Cooling & Heat & $\begin{array}{l}\text { Output Tempera- } \\
\text { ture }\end{array}$ & ${ }^{\circ} \mathrm{C}$ & $\mathrm{COP}=\mathrm{Q}_{\mathrm{c}} / \mathrm{Q}_{\mathrm{h}}$ & Cooling & $\mathrm{kW}$ \\
\hline & System & & Electricity & $\begin{array}{l}\text { Coefficient of } \\
\text { Performance } \\
\end{array}$ & - & & & \\
\hline & & & & $\begin{array}{l}\text { Initial Investment } \\
\text { Cost }\end{array}$ & $\$$ & & & \\
\hline
\end{tabular}

Table 1. Power Conversions Systems and Their Characteristics 


\begin{tabular}{|c|c|c|c|c|c|c|c|c|}
\hline $\begin{array}{l}\text { Energy } \\
\text { Source }\end{array}$ & $\begin{array}{l}\text { Power Con- } \\
\text { version }\end{array}$ & Purpose & Input & Parameter & Unit & Transfer Function & Output & Unit \\
\hline \multirow{12}{*}{$\begin{array}{l}\text { Natural } \\
\text { Gas }\end{array}$} & \multirow{7}{*}{$\begin{array}{l}\text { Cogeneration } \\
\text { Unit }\end{array}$} & \multirow{7}{*}{$\begin{array}{l}\text { Heat } \\
\text { Electricity }\end{array}$} & \multirow{7}{*}{ Fuel } & $\begin{array}{l}\text { Electricity } \\
\text { Power Capacity }\end{array}$ & $\mathrm{kWh}$ & \multirow{4}{*}{$\eta e=W / Q_{f}$} & \multirow{4}{*}{ Electricity } & \multirow{7}{*}{$\mathrm{kW}$} \\
\hline & & & & $\begin{array}{l}\text { Peak Electricity } \\
\text { Load }\end{array}$ & $\mathrm{kW}$ & & & \\
\hline & & & & $\begin{array}{l}\text { Electricity Heat } \\
\text { Ratio }(C)\end{array}$ & - & & & \\
\hline & & & & Peak Heat Load & $\mathrm{kW}$ & & & \\
\hline & & & & $\begin{array}{l}\text { Primary Rate of } \\
\text { Energy Recov- } \\
\text { ery (PASS) }\end{array}$ & - & \multirow{3}{*}{$\eta_{h}=Q_{h} / Q_{f}$} & \multirow{3}{*}{ Heat } & \\
\hline & & & & $\begin{array}{l}\text { Fuel Consump- } \\
\text { tion }\end{array}$ & $\$$ & & & \\
\hline & & & & $\begin{array}{l}\text { Initial Invest- } \\
\text { ment Cost }\end{array}$ & $\$$ & & & \\
\hline & \multirow{5}{*}{ Boiler } & \multirow{5}{*}{ Heat } & \multirow{5}{*}{ Fuel } & Capacity & $\mathrm{kW}$ & \multirow{5}{*}{$\eta_{h}=Q_{h} / Q_{f}$} & \multirow{5}{*}{ Heat } & \multirow{5}{*}{$\mathrm{kW}$} \\
\hline & & & & Cascade & - & & & \\
\hline & & & & $\begin{array}{l}\text { Boiler Effi- } \\
\text { ciency }\end{array}$ & - & & & \\
\hline & & & & Fuel Price & $\$$ & & & \\
\hline & & & & $\begin{array}{l}\text { Initial Invest- } \\
\text { ment Cost }\end{array}$ & $\$$ & & & \\
\hline \multirow{13}{*}{ Electricity } & \multirow{3}{*}{$\begin{array}{l}\text { Vapor Com- } \\
\text { pression Re- } \\
\text { frigerant Sys- } \\
\text { tem }\end{array}$} & \multirow{3}{*}{ Cooling } & \multirow{3}{*}{ Electricity } & $\begin{array}{l}\text { Cooling Capac- } \\
\text { ity }\end{array}$ & $\mathrm{kW}$ & \multirow{3}{*}{$C O P=Q_{d} / W$} & \multirow{3}{*}{ Cooling } & \multirow{3}{*}{$\mathrm{kW}$} \\
\hline & & & & $\begin{array}{l}\text { Coefficient of } \\
\text { Performance }\end{array}$ & - & & & \\
\hline & & & & $\begin{array}{l}\text { Initial Invest- } \\
\text { ment Cost }\end{array}$ & $\$$ & & & \\
\hline & \multirow{7}{*}{$\begin{array}{l}\text { Ground } \\
\text { Source Heat } \\
\text { Pump }\end{array}$} & \multirow{7}{*}{$\begin{array}{l}\text { Heat } \\
\text { Cooling }\end{array}$} & \multirow{7}{*}{ Electricity } & $\begin{array}{l}\text { Ground Tem- } \\
\text { perature }\end{array}$ & ${ }^{\circ} \mathrm{C}$ & \multirow{4}{*}{$C O P_{h}=Q_{h} / W$} & \multirow{4}{*}{ Heat } & \multirow{7}{*}{ kW } \\
\hline & & & & $\begin{array}{l}\text { Cooling Capac- } \\
\text { ity }\end{array}$ & $\mathrm{kW}$ & & & \\
\hline & & & & $\begin{array}{l}\text { Heating Capac- } \\
\text { ity }\end{array}$ & $\mathrm{kW}$ & & & \\
\hline & & & & $\begin{array}{l}\text { Ambient Tem- } \\
\text { perature }\end{array}$ & ${ }^{\circ} \mathrm{C}$ & & & \\
\hline & & & & $\begin{array}{l}\text { Cooling Coeffi- } \\
\text { cient of Perfor- } \\
\text { mance }\end{array}$ & - & \multirow{3}{*}{$C O P_{c}=Q_{d} / W$} & \multirow{3}{*}{ Cooling } & \\
\hline & & & & $\begin{array}{l}\text { Heating Coeffi- } \\
\text { cient of Perfor- } \\
\text { mance }\end{array}$ & - & & & \\
\hline & & & & $\begin{array}{l}\text { Initial Invest- } \\
\text { ment Cost }\end{array}$ & $\$$ & & & \\
\hline & \multirow{3}{*}{$\begin{array}{l}\text { Variable Re- } \\
\text { frigerant } \\
\text { Flow }\end{array}$} & \multirow{3}{*}{ Cooling } & & $\begin{array}{l}\text { Cooling Capac- } \\
\text { ity }\end{array}$ & $\mathrm{kW}$ & & & \\
\hline & & & Electricity & $\begin{array}{l}\text { Coefficient of } \\
\text { Performance }\end{array}$ & - & $C O P=Q_{d} / W$ & Cooling & $\mathrm{kW}$ \\
\hline & & & & $\begin{array}{l}\text { Initial Invest- } \\
\text { ment Cost }\end{array}$ & $\$$ & & & \\
\hline
\end{tabular}




\section{Simulation}

This section of the study discusses the details of the work carried out and the assumptions about the Excel ${ }^{\mathrm{TM}}$ based simulation program developed. A data source has been obtained with the simulation study, so that the work is also available for buildings with different loads. In the study, it is possible to create new hybrid systems with power converters, power sources used by power converter systems or changes in the capacities of power converter systems that are required to meet the same load. The technoeconomic and environmental analysis of each new hybrid system created with this data source that can be applied to each building is made and the simulation outputs are reached. Table 2 and 3 are the input and output screens of the simulation program respectively.

Table 3. Simulation Inputs

\begin{tabular}{|l|l|}
\hline 1. Climate Information & Data \\
\hline Solar Radiation $[\mathrm{W} / \mathrm{m} 2]:$ & \\
\hline Ambiant Temperature $\left[{ }^{\circ} \mathrm{C}\right]:$ & \\
\hline Ground Temperature $\left[{ }^{\circ} \mathrm{C}\right]:$ & \\
\hline 2. Building Information & \\
\hline Building Heat Load $[\mathrm{kW}]:$ & \\
\hline Building Cooling Load $[\mathrm{kW}]:$ & \\
\hline Building Electricity Load $[\mathrm{kW}]:$ & \\
\hline Building Hot Water Load $[\mathrm{kW}]:$ & \\
\hline $\begin{array}{l}\text { 3. Power Conversion Systems } \\
\text { Information }\end{array}$ & \\
\hline Equipment Capacity $[\mathrm{kWh}]:$ & \\
\hline Equipment Efficiency : & \\
\hline Equipment Unit Price $[\$ / \mathrm{kWh}]:$ & \\
\hline Equipment Installation Price $[\$]:$ & \\
\hline Number of Equipment : & \\
\hline
\end{tabular}

Table 3. Simulation Outputs

\begin{tabular}{|l|l|}
\hline 1. Technical Outputs & Results \\
\hline Flat Plate Collector Area $\left[\mathrm{m}^{2}\right\rceil:$ & \\
\hline $\begin{array}{l}\text { Potovoltaic / Potovoltaic Thermal Hybrid } \\
\text { Panel Area }\left[\mathrm{m}^{2}\right]:\end{array}$ & \\
\hline Electricity Consumption $\lceil\mathrm{kW}]:$ & \\
\hline Natural Gas Consumption $\lceil\mathrm{kW}\rceil:$ & \\
\hline 2. Economical Outputs & \\
\hline Total Investment Cost $[\$]:$ & \\
\hline Total Operation Cost $\lceil \$]:$ & \\
\hline Total Cost $[\$]:$ & \\
\hline Pay Back Period $\lceil$ Year $]:$ & \\
\hline 3. Environmental Output & \\
\hline $\mathrm{CO}_{2}$ Income $[\$]:$ & \\
\hline
\end{tabular}

The simulation program provides a detailed analysis of the technical, economic and environmental aspects for the end user to meet the loads of a building designed with innovative methods.

\section{Case Study and Scenarios}

In this study, Eser Green Building has been used as case study and the heating, cooling and electric loads of Eser Green Building are the inputs of $\mathrm{Excel}^{\mathrm{TM}}$ - based simulation program. The domestic water load of the building was included in the study, by assuming that the daily requirement at $60^{\circ} \mathrm{C}$ was $50 \mathrm{~L}$. It was accepted that the study was conducted in Ankara/ Turkey and the annual operating time was 3000 hours. It has been possible to evaluate the innovative hybrid systems developed by the construction of similar assumptions such as the use of building loads and working time under the same conditions. In this section, the current status of Eser Green Building, building loads and the existing power converters used in Eser Green Building are shared with 2 different innovative system scenarios which are presented as an alternative to the conventional system.

\subsection{Current status of Eser Green Building}

Eser Holding Green Building has received the first LEED Platinum green building certification in Turkey. Eser Green Building is designed to save water and energy, to prevent environmental pollution, to use the resources optimally and to produce some of the energy it needs by using renewable energy sources within its own structure [7]. Heating and cooling loads of the building are recorded all year round. In line with this data, Fig. 1 gives monthly cooling and heating load. The electrical peak load is used for the electrical load of Eser Green Building, as in heating and cooling loads.
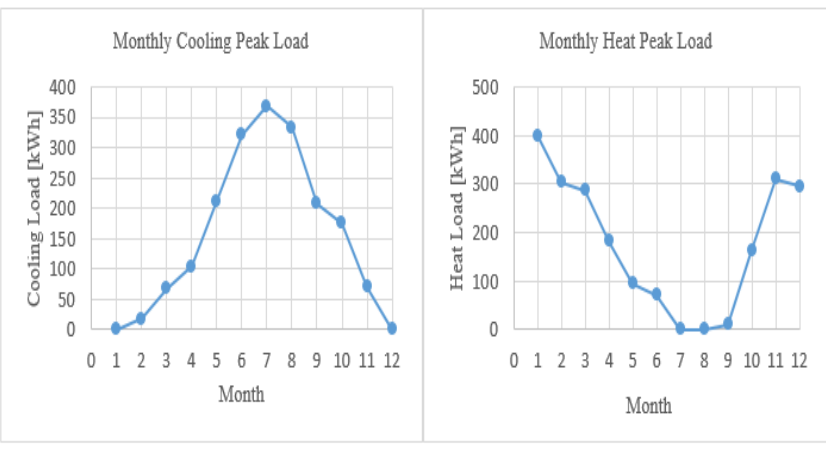

Figure 1. Monthly Heating and Cooling Loads of Eser Green Building

In Table 4, the peak loads of Eser Green Building are presented. The electrical peak load is used for the electrical load of Eser Green Building, as in heating and cooling loads.

Table 3. Peak Loads of Eser Green Building

\begin{tabular}{|c|c|c|c|}
\hline & Heat Load [kW] & Electricity Load [kW] & Cooling Load [kW] \\
\hline Peak Load & 400 & 420 & 368 \\
\hline
\end{tabular}

In Table 4, Eser Green Building simulation outputs have shared. The main outputs of Eser Green Building are investment cost (IC), operating cost (OC), total cost (TC), total carbon dioxide emission gain (TCc) and payback period (PP). The following assumptions were 
taken into account for the calculation of the main outputs. These;

- Operation period of Eser Green Building is 3000 hours per year,

- When calculations were made for monthly heating and cooling loads, the peak load was taken into account for the electrical load.

- Installation cost is included in the investment cost account,

- Carbon emissions resulting from natural gas and electricity consumption are taken into consideration in the calculation of preventing carbon dioxide emissions.

Table 4. Payback Period for Eser Green Building

\begin{tabular}{|c|c|c|c|c|}
\cline { 2 - 5 } \multicolumn{1}{c|}{} & $\mathrm{IC}_{\mathrm{i}}[\$]$ & OC $_{\mathrm{i}}[\$]$ & $\mathrm{TC}_{\mathrm{c}}[\$]$ & $\mathrm{PP}[$ Year $]$ \\
\hline Eser Green Building & 1702319.4 & 35161 & 5029.4 & 11,8 \\
\hline
\end{tabular}

\subsection{Scenarios}

The scope of this section, two different scenarios were created to meet electricity, heating, cooling and hot water loads. The decision-making algorithm used in the evaluation of the scenarios is given in Fig. 2. Cogeneration system is the main component of the developed scenarios and that is always in operation. In cases where the presence of soil temperature with solar energy and electrical, heating and cooling loads are required for the heating and cooling loads, the ground source heat pump is switched on and the PV / T, PV are activated for the electrical load. If the building loads cannot be met by these energy sources or the energy sources are not available, waste heat is activated. In the same way, conventional power transformer systems are used in which natural gas and electricity are used in the event that the building loads cannot be met with ground heat or the ground heat is not available. If the building does not require heating, cooling and electricity, the algorithm gives a stop command. The decision-making algorithm used in the development of scenarios offers to the end-user the need to minimize the use of electricity and natural gas, thereby reducing environmental pollution, and increasing the ratio of innovative systems.

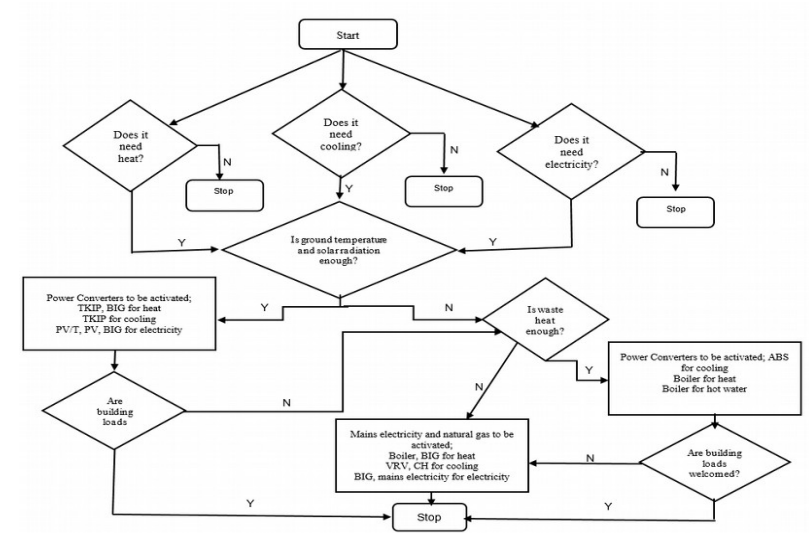

Figure 2. Decision Making Algorithm

\subsubsection{Scenario 1}

The first scenario was aimed to meet the building loads by using heating, cooling and electric loads of Eser Green Building. In the study, the daily requirement for the calculation of the hot water load was determined as $50 \mathrm{~L}$. In the scenario, as shown in the decision-making algorithm, the use of innovative energy sources, including solar energy, soil heat and residual heat, is the priority, but if the building loads are not met, the use of conventional electricity sources such as electricity and natural gas will be realized. Heating and cooling loads of Eser Green Building were taken in detail. However, there is no detailed data for electricity and hot water consumption. Peak load data is used for calculations of electricity consumption. In this direction, technoeconomic and environmental analysis were performed by determining the coverage ratios and working times of the power transformer systems selected for summer and winter seasons for the heating and cooling loads of the building. According to the annual cooling load data of Eser Green Building, cooling load over $100 \mathrm{~kW}$ during seven months of a year. The base load was chosen $100 \mathrm{~kW}$. The capacity of the waste heat-driven ABS depends directly on the heat capacity of the cogeneration and the COP of the ABS. With a capacity of $56 \mathrm{~kW}, \mathrm{ABS}$ operates at $100 \%$ capacity in the rest of the year with a $50 \%$ capacity from midJanuary to mid-February. ABS provides a very high energy efficiency due to its full capacity operation during the 11 months of the year, no longer the energy source and the lack of operating costs. The cooling capacity of TKIP is $45 \mathrm{~kW}$. Both heating and cooling are obtained from TKIP, providing support to the heating system to April and cold from TKIP from April to November. In peak loads where the ABS and TKIP do not meet the cooling load, the $\mathrm{CH}$ is activated. The capacity of $\mathrm{CH}$, is determined as $162 \mathrm{~kW}$ and 2 units are used. Selecting $\mathrm{CH} 2$ decreases operation cost. According to heating loads of Eser Green Building, there is a need for heating above $120 \mathrm{~kW}$ in 7 months of 12 months and therefore taken as a base load of $120 \mathrm{~kW}$. The heating capacity of TKIP is $45 \mathrm{~kW}$ and heat is obtained until April. The capacity of the cogeneration is $81 \mathrm{~kW}$ and the cogeneration, which is used for both heat generation and electricity generation, is used for 12 months of the year. In case of peak loads where TKIP and cogeneration are not sufficient to meet the heating load, KA is activated. KA has a total capacity of 110 $\mathrm{kW}$. The cascade system used in KA. In case the first boiler cannot meet the heating load, second boiler and then the third boiler can be activated, it saves the natural gas. In order to meet the electrical burden of Eser Green Building, 40 solar-powered PV units with a capacity of loads $0.75 \mathrm{~kW}$ are used. The monocrystalline silicone is highest power generation capacity for the same surface area [6]. For this reason, the selected type of PV in the scenario-1 capacity is monocrystalline silicone. The electricity generation capacity of the cogeneration 
system is $50 \mathrm{~kW}$. When the PV and cogeneration are not sufficient to meet the electrical load, the mains power is switched on. It was used DT and TKIP to cover the hot water load of Eser Green Building. When TKIP meets the cooling load, DT is activated to meet hot water demand. In the hybrid system, 55 DTs of $1 \times 2 \mathrm{~m} 2$ were used. The process flow diagram for the loads they meet with the power conversion systems used in Scenario-1 is given in Figure 3.

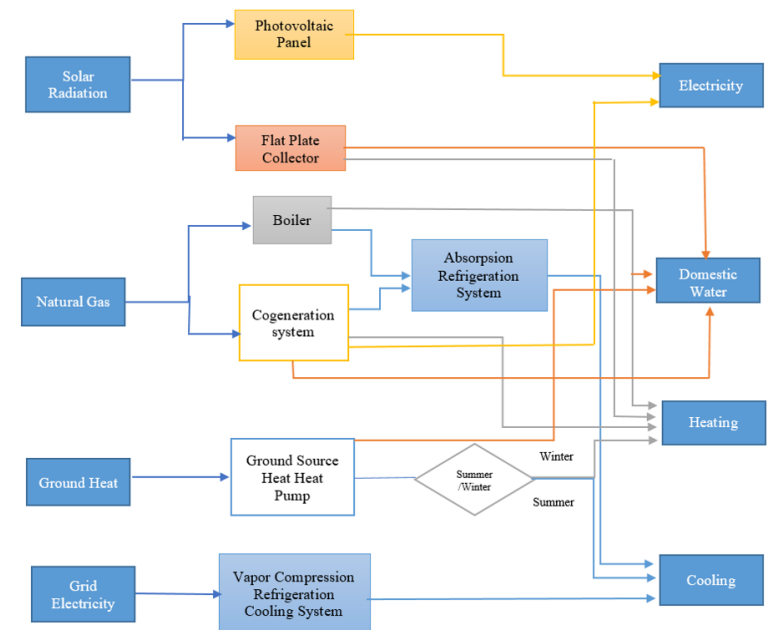

Figure 3. Process Flow Diagram for Scenario-1

Techno economic and environmental analyses were conducted for scenario-1 using the simulation developed within the scope of this study. Table 5 presents the results obtained under Scenario-1.

Table 5. Payback Period for Scenario-1

\begin{tabular}{|c|c|c|c|c|}
\hline & $I C_{i}[\$]$ & $O C_{i}[\$]$ & $T C_{C}[\$]$ & PP [Year] \\
\hline Scenario-1 & 1967953.6 & 32297.4 & 7320.9 & 13.2 \\
\hline
\end{tabular}

\subsubsection{Scenario 2}

The second scenario developed is similar to the first scenario, but is differentiated by the capacities of the power converter systems and the power transformer systems used in obtaining electricity, cooling and hot water. In this context, to meet the heating load of the building TKIP, cogeneration and KA to meet the cooling load of the building ABS, TKIP and VRV, to meet the electricity load of the building PV/T and cogeneration. to meet the hot water load of the building TKIP and PV/T were used. According to annual cooling loads of Eser Green Building, it is needed to be over $100 \mathrm{~kW}$ in 7 months of 12 months and and the capacity of innovative power conversion systems is designed to meet $20 \%$ more than $100 \mathrm{~kW}$ selected as base load. The capacity of the waste heat-driven ABS depends directly on the heat capacity of the cogeneration and the COP of the ABS. The ABS of $80 \mathrm{~kW}$ is not operational from January to the end of February and operates at $100 \%$ capacity in the rest of the year. ABS provides a very high energy efficiency due to its full capacity operation during the 10 months of the year, no longer the energy source and the lack of operating costs. The cooling capacity of TKIP is $40 \mathrm{~kW}$. Both heating and cooling are obtained from TKIP, providing support to the heating system to April and cold from TKIP from April to November. VRV is activated when peak loads where ABS and TKIP are insufficient to meet the cooling load. The VRV with energy source mains power has a total capacity of 121 $\mathrm{kW}$ and has 2 units. Selecting VRV 2 decreases the operation cost. According to heating loads of Eser Green Building, there is a need for heating above $120 \mathrm{~kW}$ in 7 months of 12 months and the capacity of the innovative power transformer systems is designed to meet $30 \%$ more than the selected $120 \mathrm{~kW}$ of base load. The heating capacity of TKIP is $40 \mathrm{~kW}$ and heat is obtained until April. The capacity of the cogeneration is $115 \mathrm{~kW}$ and the cogeneration, which is used for both heat generation and electricity generation, is used for 12 months of the year. case of peak loads where TKIP and cogeneration are not sufficient to meet the heating load, KA is activated. The KA system, which has a total capacity of $81 \mathrm{~kW}$, has 2 units. The cascade system used in KA. To meet the electrical load of Eser Green Building, 45 pieces of PV / T with a capacity of $0.25 \mathrm{~kW}$ were used. The monocrystalline silicon has the same area and has the highest electricity production capacity [6]. For this reason, $\mathrm{PV} / \mathrm{T}$ is the type of monocrystalline silicone chosen for the scenario-2 capacity. The electricity generation capacity of the cogeneration system is $70 \mathrm{~kW}$. When the PV / T and cogeneration are not sufficient to meet the electrical load, the mains electricity is switched on. PV / T and TKIP were used to cover the hot water load. PV / T is activated when the TKIP meets the cooling load. The process flow diagram for the loads they meet with the power conversion systems used in Scenario-2 is given in Figure 4.

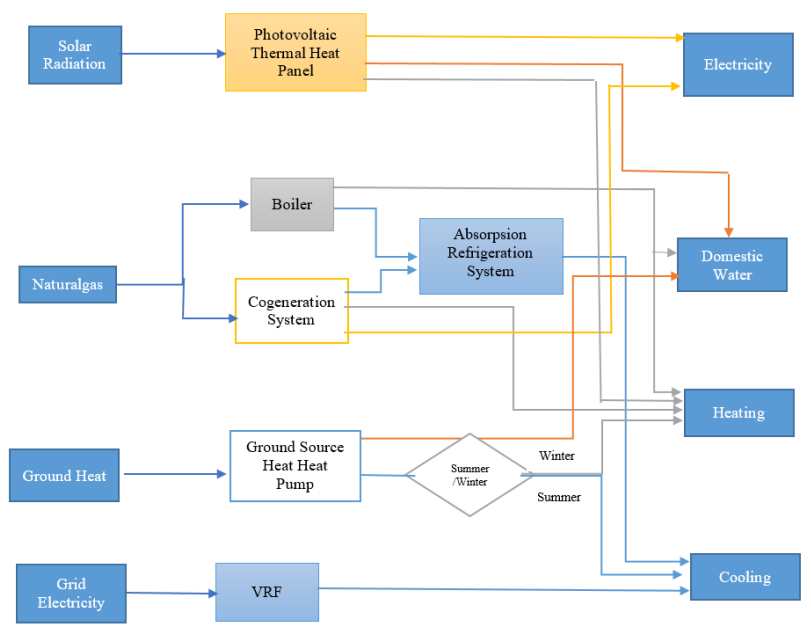

Figure 4. Process Flow Diagram for Scenario-2

Techno economic and environmental analyses were conducted for scenario- 2 using the simulation developed. Table 6 presents the results obtained under Scenario- 2 . 
Table 6. Payback Period for Scenario-2

\begin{tabular}{|l|l|l|l|r|}
\cline { 2 - 5 } \multicolumn{1}{c|}{} & C $_{i}[\$]$ & OC $_{i}[\$]$ & TC $_{C}[\$]$ & PP [Year] \\
\hline Scenario-2 & 947773.5 & 80146.1 & 8884.7 & 9.2 \\
\hline
\end{tabular}

\subsubsection{Comparison of current situation and developed scenarios}

Eser Green Building and the simulation output screen of innovative scenarios are given in Table 7 . The scenario with the longest payback period is Scenario-1, because the cost of the scenario- 1 is higher than the investment cost. Scenario-2's payback period is shorter than Scenario-1 and Eser Green Building, this is due to low investment costs and the amount of carbon dioxide emissions. Scenario-2 has the highest operating system. The main reason for rising operating costs is the increase in the use of traditional resources such as electricity and natural gas.

Table 7. Simulation Output Screen

\begin{tabular}{|c|c|c|c|}
\hline \multicolumn{4}{|l|}{ SIMULATION OUTPUT SCREEN } \\
\hline 1. TECHNICAL OUTPUTS & EGB & Scenario-1 & Scenario-2 \\
\hline Plat Plate Collector Area $\left[\mathrm{m}^{2}\right]$ : & 8 & 110 & - \\
\hline $\begin{array}{l}\text { Photovoltaic Panel / Photovoltaic Thermal } \\
\left.\text { Hybrid Panel Areal } \mathrm{m}^{2}\right] \text { : }\end{array}$ & 45 & 51,4 & 28,8 \\
\hline Electricity Consumption $[k W h]$ : & 128,7 & 131,6 & 288,8 \\
\hline Naturalgas Consumption[ $[\mathrm{kWh}]$ : & 403,0 & 372,7 & 559,1 \\
\hline \multicolumn{4}{|l|}{ 2. ECONOMIC OUTPUTS } \\
\hline Total Investment Cost $[\$]$ : & 1702319,4 & 1967953,6 & 947773,5 \\
\hline Total Operating Cost [\$]: & 35161 & 32297,4 & 80146,1 \\
\hline Total Cost [\$]: & 1737480,8 & 2000250,9 & 1027919,6 \\
\hline Payback Period $[\mathrm{Yll}]$ : & 11,8 & 13,2 & 9,2 \\
\hline \multicolumn{4}{|l|}{ 3. ENVIRONMENTAL OUTPUTS } \\
\hline $\mathrm{CO}_{2}$ Gain $[\$]$ & 5029,4 & 7320,9 & 8884,7 \\
\hline
\end{tabular}

Considering the environmental impact of cogeneration energy source natural gas, the increase in the capacity of the cogeneration power converter system increases the environmental impact, but the environmental impact of the same capacity cogeneration power converter system may differ. In this sense, the determination of the environmental impact of the innovative hybrid system should be evaluated together with all power conversions that constitute the innovative system. The graph for this situation is given in Figure 5 below.

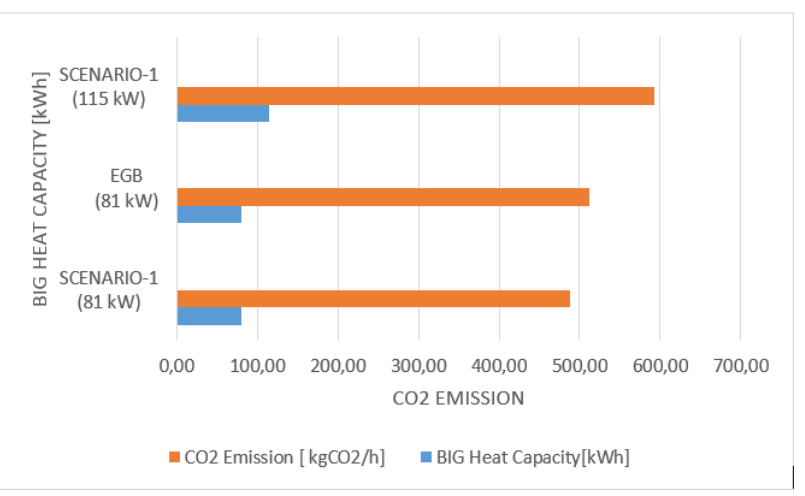

Figure 5. Cogeneration Heat Capacity Effect on Environmental

With the cogeneration system, the coverage ratio is used to determine the effect of all power converting systems that form the hybrid system. The effect of the change in the coverage ratio of the cogeneration system and the effect of the payback period on the purpose of the operation and the reduction of carbon dioxide emissions are given in Figure 6 and Figure 7.

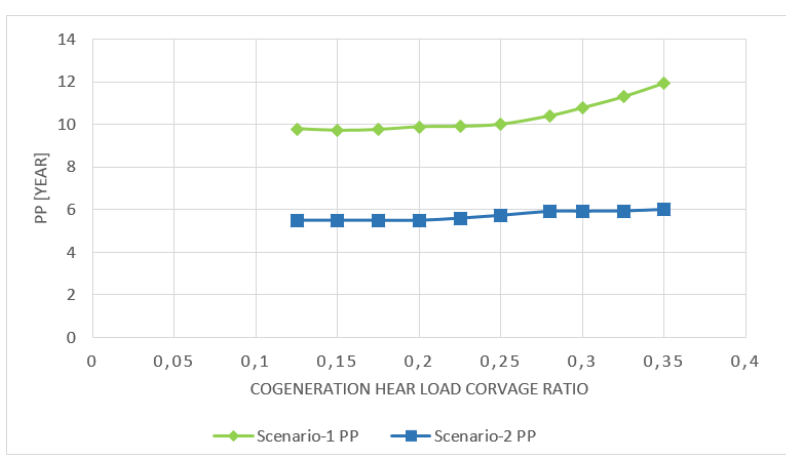

Figure 6. Cogeneration Heat Capacity Effect on Payback Period

Increasing the capacity of the cogeneration system also increases the coverage ratio of cogeneration. This situation increases both the operating cost and investment cost due to capacity and natural gas consumption. As a result, the increase in the coverage ratio of cogeneration increases the repayment period. Another result obtained the cogeneration system is approximately parallel in the graph plotted for scenario- 1 and scenario- 2 up to the value of $\mathrm{KO} 0.25$, while the inclination trend in scenario- 1 after 0.25 is higher than scenario-2 the inclination trend. This can be explained by considering all power converters in the innovative hybrid system. The percentage of the increased share of the cogeneration system in the total investment cost of Scenario- 1 is relatively higher after $0.25 \mathrm{KO}$ compared to scenario-2. However, as the percentage of the share of the cogeneration system in the total operating cost for scenario-1 does not show the same upward trend as the total investment cost. At the same time, the cogeneration system for scenario-2 was found to be more stable because the change the total investment cost and the increase in the total operating cost trends are same. The reason why the cogeneration system in Scenario-2 is low in total investment cost according to scenario- 1 is that in scenario-2, unlike scenario-1, $\mathrm{PV} / \mathrm{T}$ is the power converting system that dominates the total investment cost. As a result, the increase in the capacity of the cogeneration system in scenario- 2 increased the total investment cost with $\mathrm{CR}$, but this ratio still remained relatively low. 


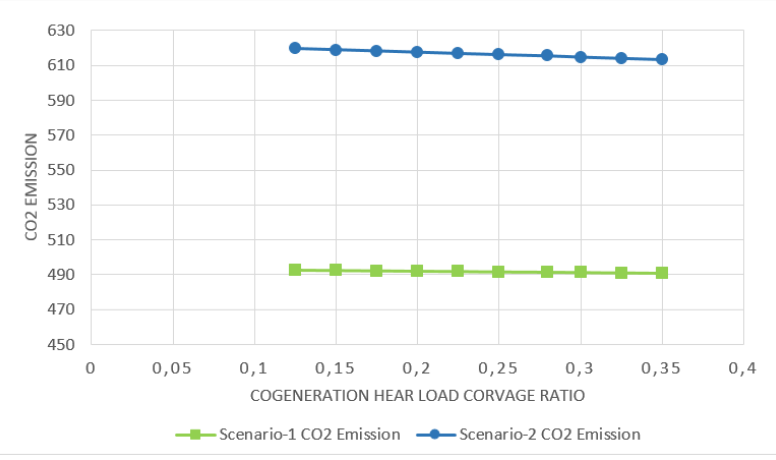

Figure 7. Cogeneration Heat Capacity Effect on Carbon Dioxide Emission

As a result, the carbon dioxide emissions have decreased with the increase in the CR of the cogeneration system, but this effect is negligible. In the developed system, the carbon dioxide emission source is not only a cogeneration system, therefore, the reduction of carbon dioxide emissions will be possible by reducing all of the conventional energy sources in the hybrid system developed.

\section{Conclusion}

Developed an innovative system, the choice of power conversion systems is great importance. When the innovative system developed is evaluated economically, the investment cost of the traditional method comes from the price paid to the boiler and the vapor compression refrigeration system. In the traditional method, operating expenses are due to natural gas and electricity consumption. The investment cost was determined according to the capacities of the power converting systems in innovative system. Operating costs are neglected in power conversion systems using renewable energy, waste heat and ground temperature in innovative system. In the innovative method, operating costs and carbon dioxide emissions have been reduced, which contributes positively to the payback period. Excel ${ }^{\mathrm{TM}}$ based simulation program was used in the study. A data source has been obtained by the simulation study, techno economic and environmental analysis of each new hybrid system created by this data source and the techno economic and environmental outputs of the simulation are reached. As a result of the simulation, technical, economic and environmental outputs are presented. The coverage ratio has been used. The simulation results show that increasing the use of innovative power conversion systems shortens the payback period and increases carbon dioxide recovery. Increasing the number of equipment increase the investment cost and decrease the operating cost. This is because the power converter system is used to prevent full capacity fuel or utility electricity. The payback period increases as the investment cost increases, which is one of the parameters affecting the payback period. However, since it is the fuel of the device, which is one of the most important factors affecting the cost of operation, it is not possible to make a direct connection between the payback period and the operating cost. In the study, the base loads were met with innovative power converting systems and the carbon dioxide emission values of these systems were accepted as zero. The increase in carbon dioxide recovery is related to the decrease in the payback period. In future studies to carry out hourly measurements as well as heating and cooling loads of the electrical loads, wear rate of power coverage systems to operating cost, reduction of load fluctuations by storing heat and cold, considering the reduction of the need for conventional systems for peak loads and the inclusion of building automation systems will create a more sensitive system.

\section{References}

1. P. Iodice, M. Dentice, Abagnale, C. M. Cardone, Energy, Economic and Environmental Performance Appraisal of a Trigeneration Power Plant For a New District: Advantages of Using a Renewable Fuel. Applied Thermal Engineering 95, 330- 338 (2016)

2. B. I. Askari, O. M. Sadegh, M. Ameri, Energy Management and Economics of Trigeneration System Considering the Effect of Solar PV, Solar Collector and Fuel Price. Energy For Sustainable Development 26, 43-55 (2015).

3. A. G. Memon, R. A. Memon, Parametric Based Economic Analysis of a Trigeneration System Proposed For Residental Buildings. Sustainable Cities and Society 34, 144-158 (2017).

4. X. Zhao, L. Fu, F. Li, H. Liu, Design and Operation of a Tri-Generation System For a Station in China. Energy Conversion and Management 80, 391- 397 (2014).

5. G. Emmi, A. Zarella, M. De Carli, A. Galgaro, An Analysis of Solar Assisted Ground Heat Pumps In Cold Climates. Energy Conversion and Management 106, 660-675 (2015).

6. Yazman, Ercan, 0.4 MW Tri-Generation System Modelling, Engine Selection and Yield Analysis, Master Thesis, Akdeniz University, Antalya, (2015)

\section{7. http://www.eseryesilbina.com/}

